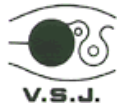

\title{
レーザ変位計を用いた薄膜撓み計測による 翼表面圧力分布の測定*
}

\author{
手塚 亜聖 11

\section{Surface Pressure Distribution Measurement on an Airfoil using a Laser Displacement Sensor and Deflected Films}

\begin{abstract}
Asei TEZUKA
ABSTRACT

For the measurement of the surface pressure distribution, we can use the differential pressure transducer as a conventional pressure measurement of fluid, with plumbing pipes inside the airfoil-section model for delivering the static-pressure from the surface of the model. The surface pressure distribution is measured with high-precision, but the cost for producing the model is expensive. In this paper, new pressure-measurement system is proposed to measure the surface pressure distribution at the low-speed condition with low cost. The surface pressures are obtained by measuring the deflection of a film which is attached on the surface of the model. In the present study, a wing section model is placed $150 \mathrm{~mm}$ away from the wing tunnel wall, and the surface pressure distribution on the airfoil is measured. The results measured by the present method and the differential pressure transducer are compared. The results demonstrate that the present method yields essential information of the pressure distribution which is transformed with increasing the angle of attack.
\end{abstract}

Keywords : Wind tunnel testing, Differential pressure measurement, Laser displacement sensor

\section{1. はじめに}

科学技術の進歩により電子部品などの小型化が進んだ 結果, 数十七ンチ程度の超小型飛行機(MAV)を飛行させる ことが可能になった，MAV は，低コストで機動性の高い 観測・監視システムとした利用が期待される.

数十七ンチ程度の MAV が秒速数メートルで飛行する, レイノルズ数 $(R e$ 数 $)$ か $1.0 \times 10^{5}$ 程度の領域では, 空力性 能の $R e$ 数依存性が大きいことが知られている ${ }^{1-3)}$. しかし， 近年着目されるようになった MAV が対象となる, 低 $R e$ 数における翼の研究結果は, 航空機として実用性がある高 $R e$ 数に比べて少ない. $R e$ 数低下と共に厚さを増す境界層 内の流机は非定常性を有しているが, 十分に発達した乱流 状態とも言えず, 数值計算においては, このような流れを 正しく解くことが鍵となる ${ }^{4)}$ 。このため，MAV を設計・ 製作する上では, 様々な形状に対して実験を行い, 空力特 性を詳細に調べる必要が生じている.

* 原稿受付 2008 年 11 月 26 日

1) 正会員 早稲田大学 理工学術院 基幹理工学部 機械科学・航空 学科（广169-8555 東京都新宿区大久保 3-4-1)
一般的な圧力計測では, 表面に静圧孔を開け, 風洞側面 圧との差圧を計測する。しかし，模型内部に配管を通す作 業は工数が多く費用が高い. 感圧塗料を用いることでこの 問題は解消されるが, 酸素分圧の変化が小さい低速流への 適用を考えると, 今のところ圧力測定は容易ではないと考 えられている。

その他のアプローチによる研究として，ピエゾ素子 5) を用いた圧力測定 ${ }^{6}$ や，干渉計を用いた薄膜撓みの時間変 動の計測 7)などが挙げられる.これらの手法は, ダイアフ ラムが計測点に置かれることから, 配管による圧力測定で は難しい非定常圧力計測といった利用が期待される.

なお，ピエゾ素子を用いた計測では，模型内部への素子 の埋込, さらには, 感圧センサ部の破損などを考慮し, 素 子を交換可能な構造することなどにより, 模型の製作工数 は増加することが予想される. また, 干渉計では, 光路長 といった光学系セットアップに要する時間, そして, 迎角 をパラメータとして変化させ前縁から後縁までの多点圧 力計測を行うための光学系の調整など, 実験の作業量は膨 大になることが予想される。一方，このような薄膜の撓み を光学的に計測し圧力を検出する方法は, 感圧部の構造が 簡単であり, 模型製作や感圧部の交換が容易な点が長所で 
ある・

そこで, 筆者は, この点を生かしつつ, 既存の圧力計測 手法の代用として簡便に利用できるような計測方法とし て, レーザ変位計を用いて物体表面に張られた極薄膜の撓 みを計測することにより, 表面圧力を非接触で測定する計 測法を考案した。本研究で用いたレーザ変位計の特徴は, 光の投光部と受光部が一体となっており, 膜の撓みを容易 に計測できることである．また，トラバース装置を用いる ことで撓みの線分布を測定でき，多点圧力計測も容易に行 える. 更に，2 軸のトラバース装置を用いることで圧力分 布の面計測, 寸なわち, 圧力分布の可視化手法としての利 用も期待される.

筆者は, この手法による圧力測定の妥当性を検証するた め，供試体に差圧をかけた検証実験を行った ${ }^{8)}$. 差圧計と 比較して, $\pm 2 \mathrm{~Pa}$ から $\pm 4 \mathrm{~Pa}$ 程度の不確かさで測定が可能 であった。実際の風洞試験では，検証実験では現れない 様々な要因により, 計測精度が悪化すると予想される。 そ こで，風洞試験において計測が可能か否かを調べるため, 翼圧比 $4 \%$ の模型を製作し極薄膜の撓み測定及び静圧孔 による翼表面圧力係数分布を比較した ${ }^{9)}$.

本稿では, 極薄膜の撓み測定と静圧孔による圧力計測の 結果を示すと共に, 差圧が小さく膜の変位が小さい測定点 にて, 変形部と平坦部の形状の違いがほとんど見られず, 撓み計測の不確かさが増すことを改善する手法を提示し， この手法で計測結果が改善されることを示す.

\section{2. 測定方法}

\section{1 圧力測定方法の概要}

圧力測定方法の概念図をFig. 1 に示す. 従来の方法(Fig. 1 (a))では, 物体に働く圧力は, 風洞外部に置かれた差圧 計で測定されるため, 物体表面に静圧孔を開け, 配管を通 じて圧力を風洞外部に導出する必要がある. 本研究で提案 する圧力測定方法の概念図を Fig. 1(b)に示す. 薄膜の一方 に模型表面圧力，もう一方に風洞壁圧がかかるようにする. 圧力差がある場合，薄膜は撓み，その撓み量は差圧に応じ て変化することが期待される。この撓み量をレーザ変位計 を用いて測定できれば, 模型表面圧力と風洞壁圧との差圧 の計測が可能になる.この方法ならば, 導圧管は風洞壁圧 参照用の 1 本のみで済み, 装置の大幅な簡略化が図れる. そこで, 本研究では，同一翼型模型に静圧孔と穿孔部に薄 膜を貼付したものを製作し, 風洞試験において上記手法に よる圧力測定が可能か否かを検証した.

\section{2 レーザ変位計の選定}

本実験で用いたキーエンス社製レーザ変位計 LK-G シ リーズによる測定原理をFig. 2 に示す.レーザ発生器から 投光されたレーザ光は，対象物の表面で拡散反射する。そ の反射光の一部は受光レンズで集光され, CCD 上に結像 する. この結像位置を検出することによって, 対象物の変

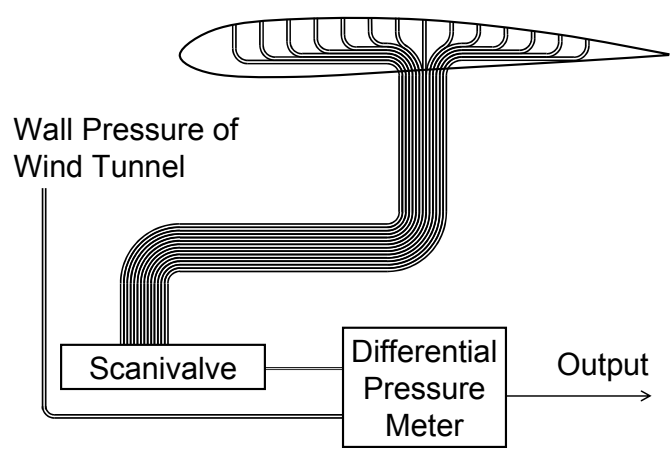

(a) Conventional approach.

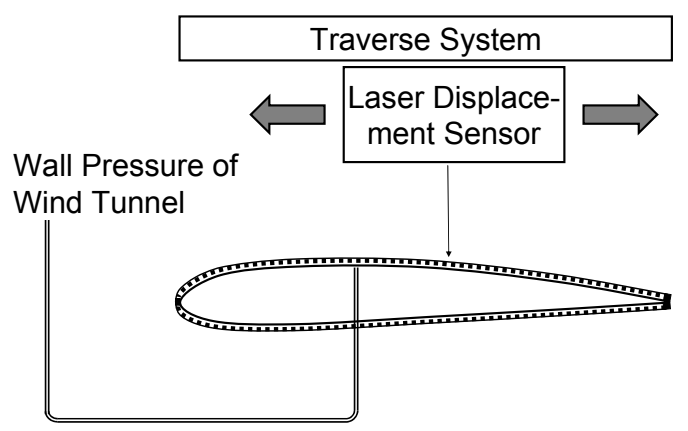

(b) Concept of the present approach.

Fig. 1 Schematic of the pressure measurement System.

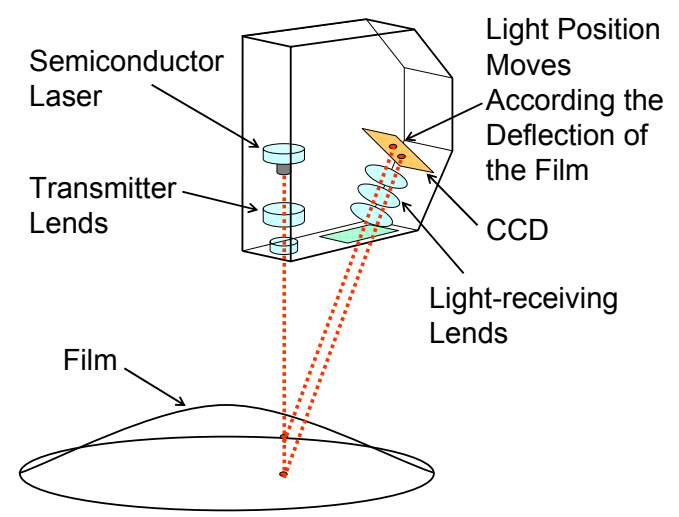

Fig. 2 Measurement principle of the film position using a laser displacement sensor.

位量を測定する. 変位計の計測精度は，レーザ出力部およ び受光部から対象物体までの基準距離に依存し，この距離 が短いほど，計測精度が向上する。一方，風洞実験での使 用を想定すると, 対象物体までの距離が長い変位計が必要 である．基準距離が $400 \mathrm{~mm}$ の変位計は誤差が大きく微 差圧測定は不可能であった ${ }^{8)}$. そこで基準距離が $150 \mathrm{~mm}$ の変位計を用いることとした。この変位計の測定範囲は $\pm 40 \mathrm{~mm}$, 直線性 $\pm 0.05 \%$ of F.S. (F.S. $= \pm 40 \mathrm{~mm}$ ), 基準 距離におけるスポット径は $\phi 120 \mu \mathrm{m}$, 測定の繰り返し精度 
は $0.5 \mu \mathrm{m}$ である.

\section{3 風洞実験装置}

本実験では東京大学工学系研究科航空宇宙工学専攻の フラッター風洞を使用した. 測定部高さ $1200 \mathrm{~mm}$, 幅 300 $\mathrm{mm}$, 縮流比 6.25 の 2 次元固定壁測定部を有する押込型 風洞である(Fig. 3 参照).一様流流速 $10 \mathrm{~m} / \mathrm{s}$ に設定した。 この一様流流速における風洞乱れは約 $0.13 \%$ あるる.

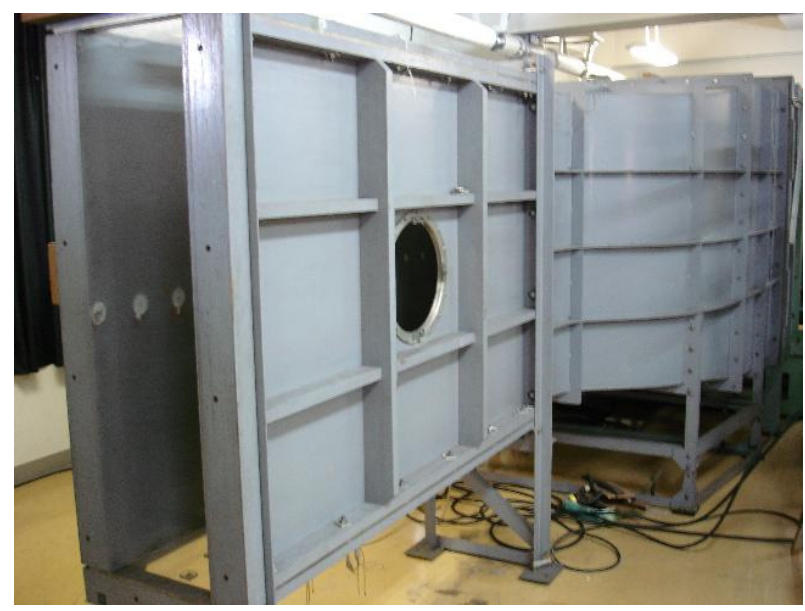

Fig. 3 The wind tunnel with a two-dimensional closed wall test section.

\section{4 薄膜形状計測装置}

薄膜形状の計測装置を Fig. 4 に示す. 模型までの基準距 離が $150 \mathrm{~mm}$ の変位計を使用するため, 幅 $300 \mathrm{~mm}$ の風 洞中央付近に翼型模型を設置し, 観測空から測定した。レ ーザ変位計ではレーザが照査された 1 点の変位を計測す るが，膜の撓みを計算するには，変位の線分布を計測する 必要がある，そこで，シグマ光機社製トラバース装置を用 いて変位計を移動させることにより, 表面形状の線分布を 測定した.

レーザ変位計およびトラバース装置の制御部には RS232C コネクタが装備されており, Visual C++.NET 2003 コンパイラを使用して作成した win32 API 通信プロ

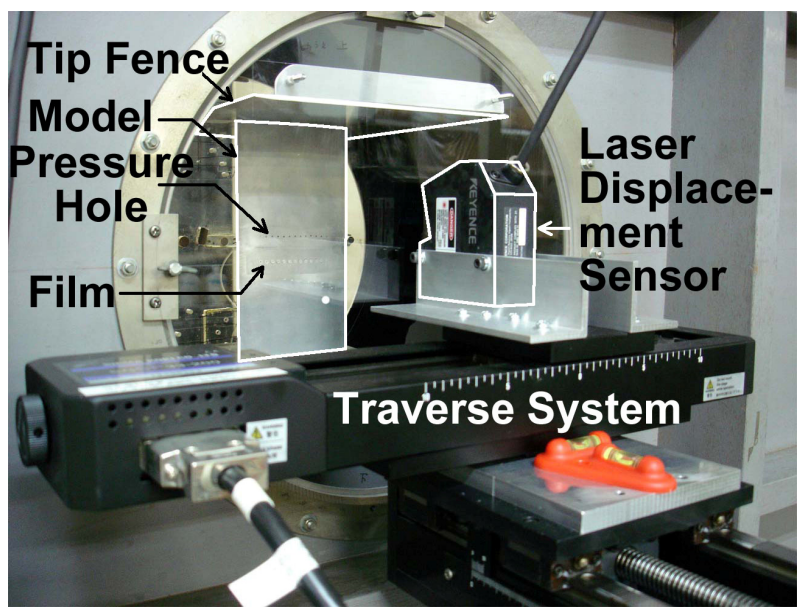

Fig. 4 Experimental setup.
グラムで計測の制御を行った.ボーレートは，トラバース

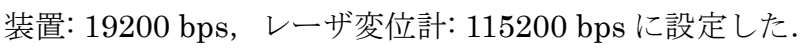
トラバース速度は $7.2 \mathrm{~mm} / \mathrm{s}$ とし, 開始後 $100 \mathrm{~ms}$ の間は $1.2 \mathrm{~mm} / \mathrm{s}$ からの加速運転を行う. 変位計のサンプリング周 期 $100 \mu \mathrm{s}$, 蓄積周期をサンプリング周期の 50 倍の設定と し, 蓄積データ数を 2000 とした. この場合, $5 \mathrm{~ms}$ 毎に測 定を行い，10 秒間分のデータを蓄積する。また，瞬間的 にみられる異常值や測定值の摇らぎを除くため, 前後 21 点での移動平均フィルタをかけた。

\section{5 翼型模型}

翼型内部に配管を施す必要があるため, Fig. 5(a)に示さ れるような，翼圧比 $4 \%$ の翼型を採用した．工作寸法精度 は土0.1 mm 以内で仕上げられていることが確認されてい る.

座標系として, 翼型前縁を原点とし翼弦方向に軸をもつ $x_{c}$ 軸と，トラバース開始位置を原点とし，トラバース方向 に軸をもつ $x t$ 軸を用いる。 $x_{c}$ 軸からみたトラバース開始 位置は迎角により変化するが, 迎角 $\alpha=0^{\circ}$ の場合 $x_{C}=15 \mathrm{~mm}$ 付近が $x_{t}=0 \mathrm{~mm}$ に相当する. $Z$ 軸は $x t$ 軸とスパン方向軸 に垂直であり，変位計が出力する值はこの軸に相当する.

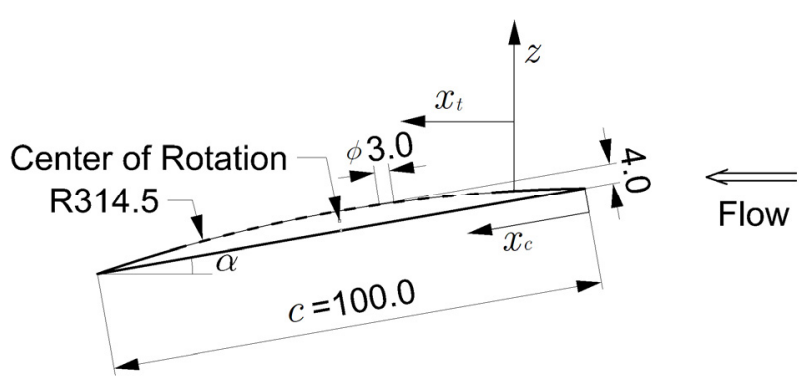

(a) Side view of the airfoil section, $x_{c}$ axis, $x_{t}$ axis, and $z$ axis. (Unit: $\mathrm{mm}$ )

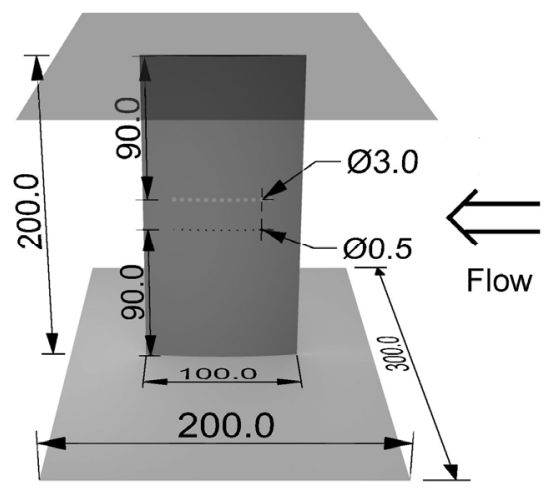

(b) Three-dimensional view of the airfoil section model and the wing tip fence. (Unit: $\mathrm{mm}$ )

Fig. 5 Drawing of the airfoil section model and the wing tip fence. 
翼端板の形状及び圧力孔の位置を Fig. 5(b)に示す. 翼上 面 $0.2 \leq x_{d} d c \leq 0.8$ の範囲にて $x_{c}=0.05 c$ 間隔で総計 13 箇 所に $\phi 0.5 \mathrm{~mm}$ 静圧孔及び $\phi 3.0 \mathrm{~mm}$ 穿孔を設けた。静圧孔 及び穿孔は，それぞれ模型側面より $90.0 \mathrm{~mm}$ 及び 110.0 $\mathrm{mm}$ の位置に設けた，穿孔部には，厚さ約 $25 \mu \mathrm{m}$ のニチ バン社製防水フィルムを張り, 穿孔内部の圧が差圧計の参 照圧と一致するように配管した. 翼弦長 $c=100 \mathrm{~mm}$, 翼幅 $b=200 \mathrm{~mm}$ であり, 翼弦長に基づく $R e$ 数は, $6.7 \times 10^{4}$ で ある。

\section{6 静圧孔による差圧計測装置}

静圧孔は, 風洞外部に貫通された配管からビニルパイプ を経由して Scanivalve 社製 Fluid switch wafer に接続さ れている. wafer は圧力変換器（Druck 社製 PDCR32,

Range $0.5 \mathrm{psi}$, 差圧型) に接続されている. この圧力変換 器で電圧に変換された後, 差動アンプを経て, データ取り 込夕装置（NEC San-ei 社製 OMNILIGHT 8M36）によ り $\mathrm{A} / \mathrm{D}$ 変換され, RS-232C 信号として, データを $\mathrm{PC} に$ 送信寸る. 圧力変換器の切り替えは 4 秒間隔で行い, その 間に 25 回の測定を行い平均值を求めた. なお圧力変換器 の精度は，本実験条件の $C_{\mathrm{p}}$ 值で \pm 0.03 である. 但し, $\Delta p$ $=p-p_{\infty}$ とするならば, $C_{\mathrm{p}}=2 \Delta p / \rho u^{2}$ である。

\section{3. 実験結果と考察}

\section{1 校正曲線の作成}

風洞を非通風状態とし, 翼型模型内部の圧をシリンジを 用いて一定間隔で加圧し, 表面形状を測定した. 翼型模型 内部と大気圧の差圧の設定方法は, $0 \mathrm{~Pa}$ から $98.0 \mathrm{~Pa}$ まで 19.6 Pa おきに加圧, 88.2 $\mathrm{Pa}$ から $9.8 \mathrm{~Pa}$ まで $19.6 \mathrm{~Pa}$ お きに減圧し, 最後に $0 \mathrm{~Pa}$ とした. 差圧が $0 \mathrm{~Pa}$ の測定が 2 回行われるが, この 2 回の測定にて変位計が出力する $z$ 軸 方向高さの值は一致しない. 何らかのオフセット值と計測 の摇らぎが加わっていると考えられたため, 2 回の平均值 を $0 \mathrm{~Pa}$ での表面形状とした。この表面形状と， $0 \mathrm{~Pa}$ での 測定值を含む各測定值の差分を計算することで, 相対高さ $\Delta z$ を計算した.

迎角 0 度での結果をFig. 6 に示す。 $0 \mathrm{~Pa}$ での測定值の み赤色の点線で表示し, 他の測定值は青色の実線で表示さ れている．この曲線は，差圧に応じて形状が変化している 部分と, 高さがフラットな部分に大別できる. 差圧に応じ て形状が変化している部分が穿孔に貼られた薄膜であり, フラットな部分が翼型表面である. 以降, $0.2 \leq x d c \leq 0.8$ の 範囲に $x_{c}=0.05 c$ 間隔で総計 13 箇所に空けられた穿孔の 最風上側を Hole 1 と名付けることにする. Hole 3, 4, 5 は それぞれ， $x d c=0.30,0.35,0.40$ の位置にある穿孔に相当 寸る.Fig. 6 では示されていないが，他の穿孔に対しても 同様の曲線が得られる。

Fig. 6 で示される曲線から薄膜の変位を算出するため に, 形状が変化している A 領域を積分し, 積分区間の長

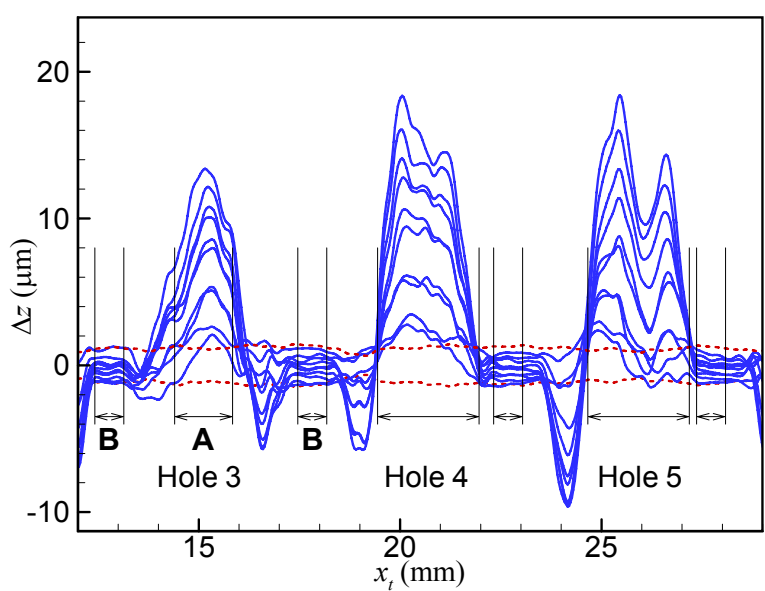

Fig. 6 Differentials of the model surface profile at regular differential pressure intervals $\left(\alpha=0^{\circ}\right)$.

さで割ることで変形部の平均高さを求め, また，同様に B 領域から算出した平坦部の平均高さを求め, 平均高さの差 から撓み量 $\Delta z_{d}$ を計算した。差圧と $\Delta z_{d}$ の関係を Fig. 7 に 示す.ここでは示されていないが，全ての穿孔に対して同 様の校正曲線を作成している. 同一の差圧に対する膜の変 位の值は，穿孔により異なり，特に, Hole 5 は差圧一変 位曲線の非線形性が強い。膜の撓み形状（Fig. 6）を見る と Hole 5 は中央部で凹んだ形状となっている，穿孔によ り差圧一変位曲線にばらつきが生じる理由として, 応力が 全くかからない条件で膜を貼ることは困難であり, 個々の 穿孔により, 膜の引張りもしくは弛み具合が異なっている と考えられるが，残留応力に応じて撓み量が変わること， 膜に貼付されたアルミ䇴の影響，などが考えられる.

膜の変位が流れに与える影響については, 膜の変位は最 大 $20 \mu \mathrm{m}$ 程度であり, 翼型模型の工作寸法精度が士 0.1 $\mathrm{mm}$ であることを考慮すると, 影響はほとんど無いと考え られる.膜の材質を変えて撓みを大きくすることで測定精 度の向上が期待されるが，この場合は，流れへの影響を調 べる必要があろう。なお，MAV の開発においては，製作

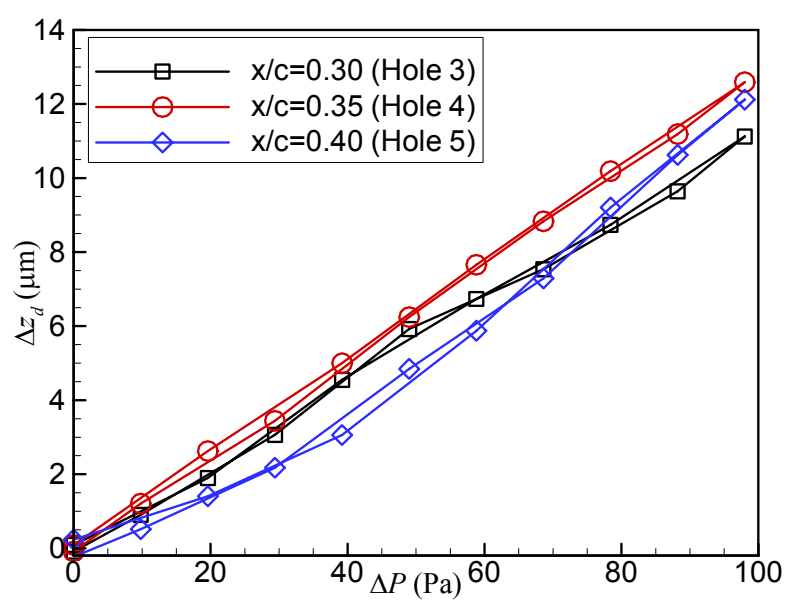

Fig. 7 Calibration curve of differential pressure vs. film deflection $\left(\alpha=0^{\circ}\right)$. 
コスト低減や降雨下での飛行などを考慮すると, 表面形状 の影響を受けにくい翼型が望ましい.

Hole 3 の下流側や Hole 4, 5 の上流側の縁において $\Delta z<0$ となる領域がある。実際の模型では，穿孔の縁とア ルミ箔の端が完全一致せずに隙間が生じているが, この隙 間を透過したレーザ光が乱反射することで表面形状測定 が困難になることが原因ではないかと考えられる．

\section{2 風洞実験における圧力係数測定結果}

風洞を通風状態として, 表面形状を複数回測定した結果 をFig. 8 に示す. Fig. 8(a)，(b) はそれぞれ，迎角 0 度及び 10 度の結果であり,Fig. 6 と同様の線種分けで表示されて いる。迎角 0 度の場合，内部空間と表面との差圧が小さい ため, 膜が殆ど変形せず, 変形部と平坦部を区別すること が困難である．そこで，Fig. 6 の曲線において変形部及び 平坦部と判断した位置に対し, 校正曲線と同様の手法で膜 の変位を計算した。

次に, Fig. 7 を使用して得られた変位から差圧を求めた。 具体的には,Fig. 7 の曲線にヒステリシスが見られるため, 加圧時と減圧時それぞれに対し, 得られた変位を挟む $2 つ$

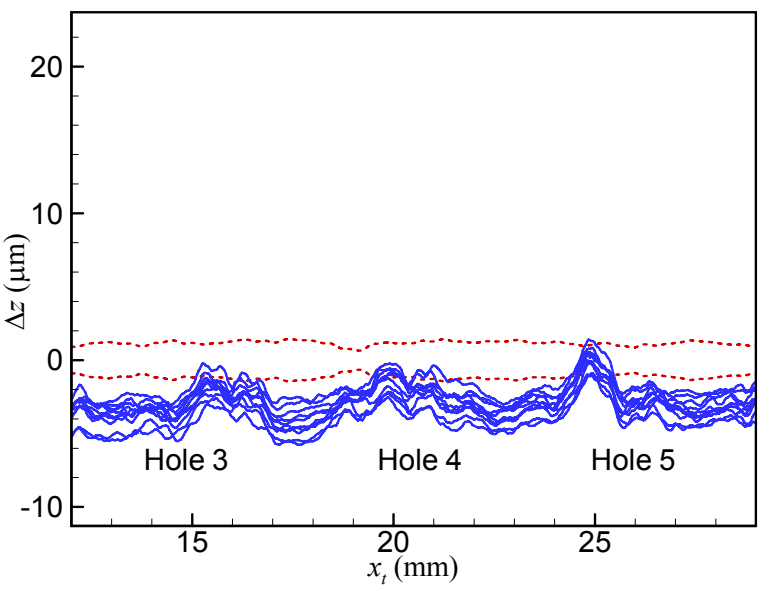

(a) $\alpha=0^{\circ}$.

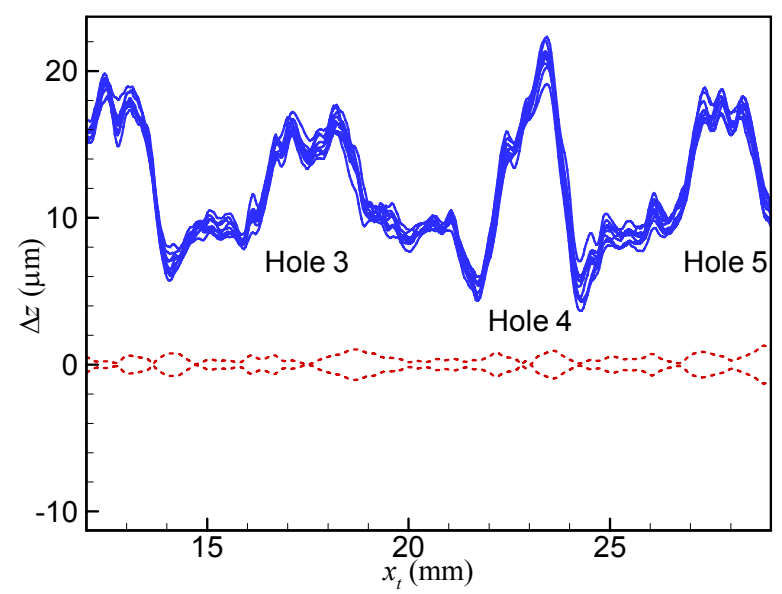

(b) $\alpha=10^{\circ}$.

Fig. 8 Differentials of the model surface profile at blowing and non-blowing condition.
の測定值を見つけ，その間を線型補完することで差圧を求 めた. 得られた差圧に対して, 差圧計と同様に処理するこ とにより圧力係数を求めた.

上記の方法で得られた圧力係数分布をFig. 9 に示す.な お, 翼上面の $20 \%$ 翼弦点から $80 \%$ 翼弦点の範囲のみ表面 圧力が計測されており, 計測結果から翼全面での表面圧力 分布を想像することは困難である。そのため, Drela らが 開発したパネル法と境界層計算 ${ }^{10}$ による X-foil により数 值的に得られた結果を併記した。

迎角 4 度の結果に見られるように, 低 $R e$ 数において翼 上面に形成される剥離泡 11$)$ を数值的に正しく求めること は難しい. 本手法で得られた圧力分布は, 差圧計による計 測結果とほぼ同じと言える. 数值計算で得られた剥離泡の 挙動の妥当性を実験的に検証する場合, 本測定法で得られ る圧力分布は有益な知見を与える.

圧力係数が大きく変化する測定点では圧力変化の特徵 がほぼ捉えられているが，低迎角時や後縁付近では，差圧 計による計測結果との差が大きくなっている.この理由と して, 差圧が小さい測定点では, 膜の撓みが小さく変形部 と平坦部の形状の違いがほとんど見られず，撓み量を計算 することが困難であることが測定值の不確かさを増す要 因になっていると思われる。

なお，低迎角での前縁側に比べ，後縁側や大迎角では， 差圧計と比較した測定值の差が大きい.この理由として， 大迎角や後縁での剥離一再付着流れは非定常であるため, 薄膜が振動し表面計測の摇らぎが増している可能性や, 翼 面が傾斜しているため変位計の計測誤差が増えること, な どの影響が考えられる. 本研究の目的は, 風洞自身の振動 の影響など計測精度の悪化が予想される風洞試験におい て, 表面圧力計測が可能か否かを調べることである. 誤差 の要因を調べることは本研究の範囲を超えるため, ここで は扱わないが, 今後の研究にて, 誤差の要因が明らかにし, 何らかの方法で非定常な圧力変動が測定できるようにな るならば, 本手法による圧力測定の新たな可能性をもたら すことになるであろう。

\section{3 変形部と平坦部の区別を明らかにする手法}

前節では, 校正曲線は非通風状態で翼内部の圧を変化さ せ，変形部と平坦部との差から撓みから作成した。翼型の 圧力係数は, 通風状態と非通風状態における表面形状測定 の差をとり, 非通風状態での変形部と平坦部の位置で撓み を計算し, 校正曲線を用いて差圧を求め変換した。しかし, 微差圧状態では膜の撓みが小さく変形部と平坦部の形状 の違いがほとんど見られず, 撓み量を計算することが困難 であった。

更に, 測定結果の不確かさを増す要因として, 通風時に おける模型及び翼端板に働く空気力により，トラバース装 置と翼との相対的な関係が多少変化することの影響など も考えられる.このため, 通風状態と非通風状態にて測定 


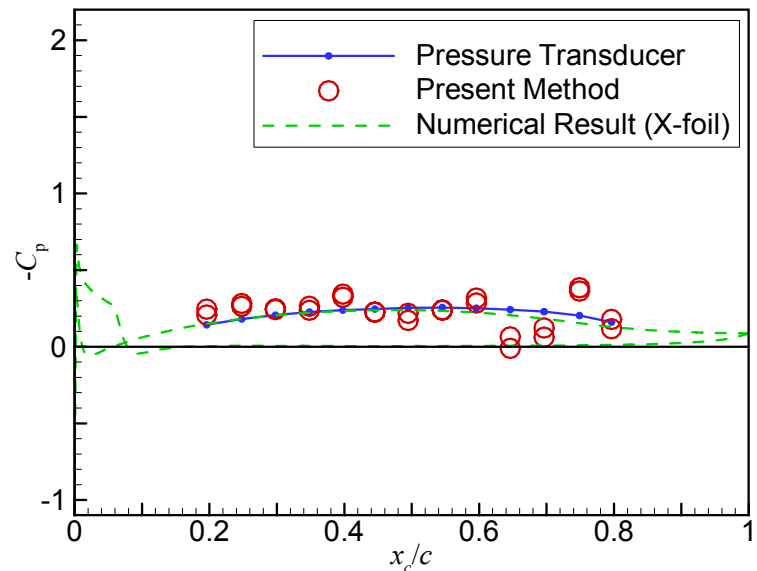

(a) $\alpha=0^{\circ}$

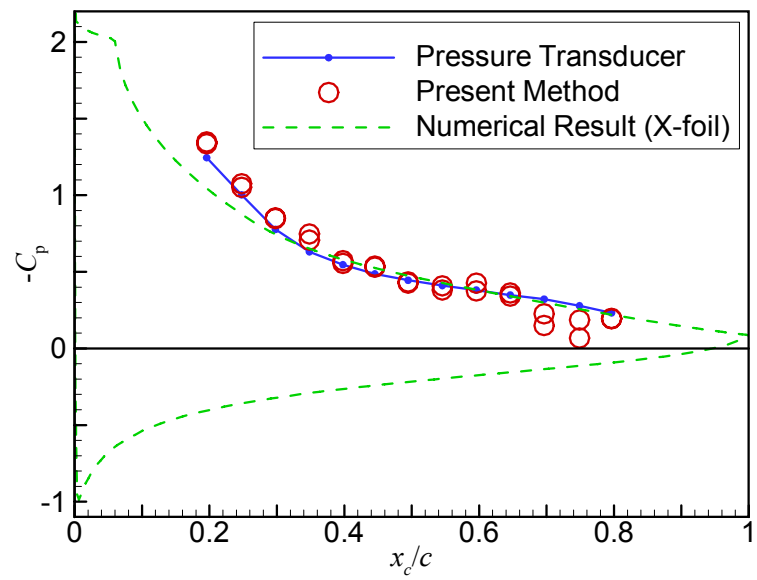

(c) $\alpha=8^{\circ}$

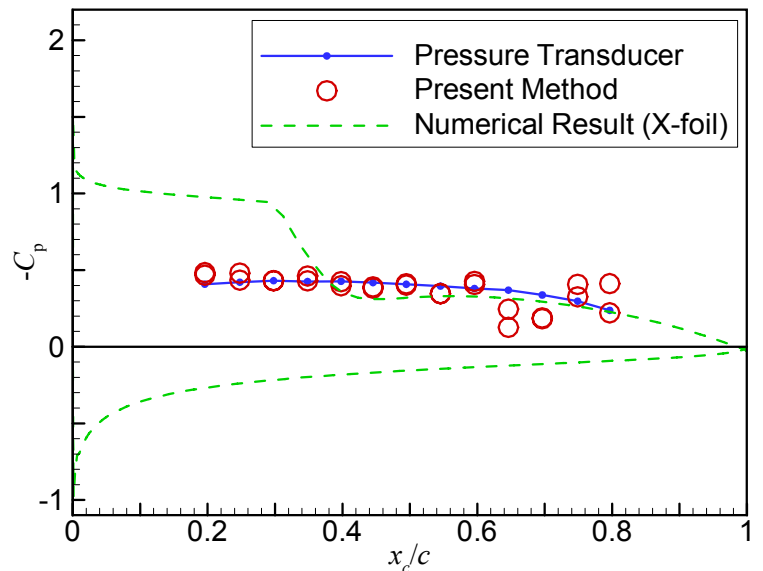

(b) $\alpha=4^{\circ}$

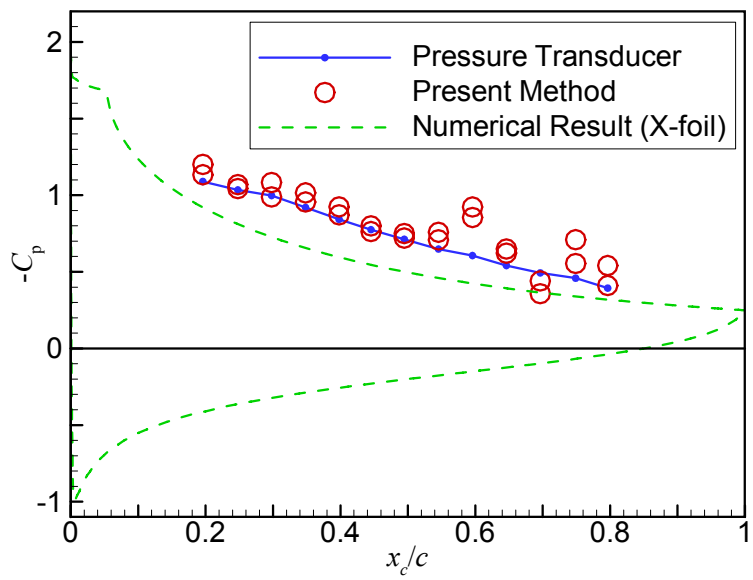

(d) $\alpha=10^{\circ}$

Fig. 9 Pressure coefficient measured by pressure transducer and the proposing method.

された, 翼模型や穿孔の位置, 膜の変形状態などは, 厳密 には一致しないと予想される.このような要因を除くこと を目的として，一部の実験においては，通風状態において も，翼内部の圧力を一定間隔(19.6 Pa おき)で加圧して形 状測定を行った。

通風状態でも翼内部の圧を変化させた計測結果に対し， 非通風状態での表面形状との差分を計算したものを Fig.

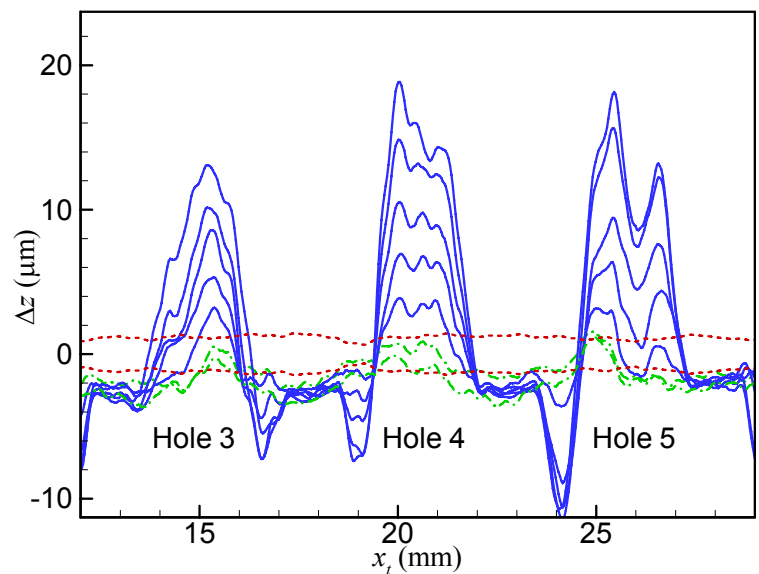

Fig. 10 Model surface profile at blowing conditions $\left(\alpha=0^{\circ}\right)$.
10 に示す. 非通風状態と通風状態における $0 \mathrm{~Pa}$ の結果は, それぞれ，赤色の点線と緑色の破線で示されている。 この 結果を用いることで微差圧状態でも変形部と平坦部の区 別が容易になる．また，通風状態同士の結果が比較できる ことにより, 穿孔の位置と膜の変形状態が正しく測定でき る.

通風状態(Fig. 10) と非通風状態(Fig. 6)の結果に対し撓

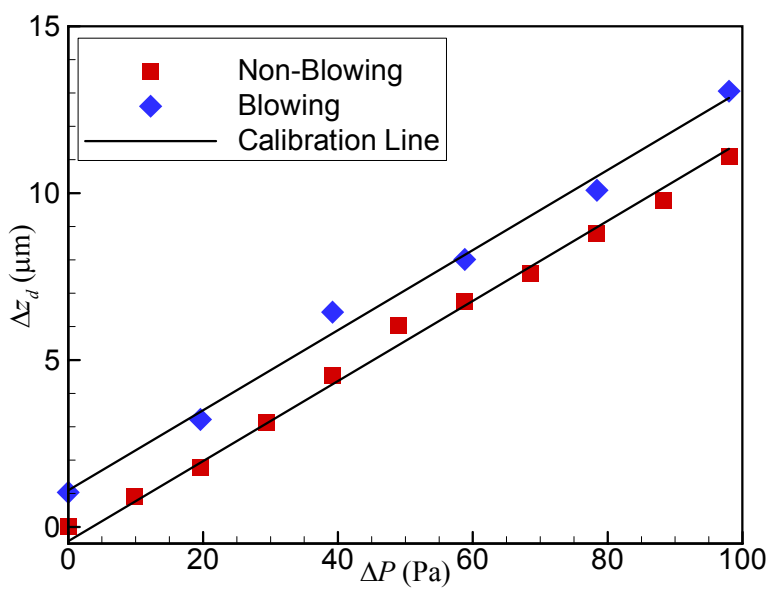

Fig. 11 Calibration line at both non-blowing and blowing condition $\left(\alpha=0^{\circ}\right.$, Hole 4$)$. 


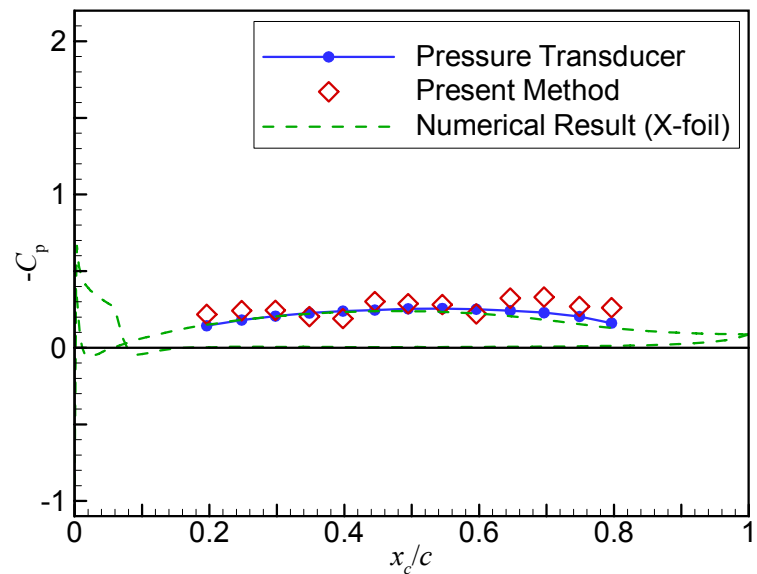

(a) $\alpha=0^{\circ}$

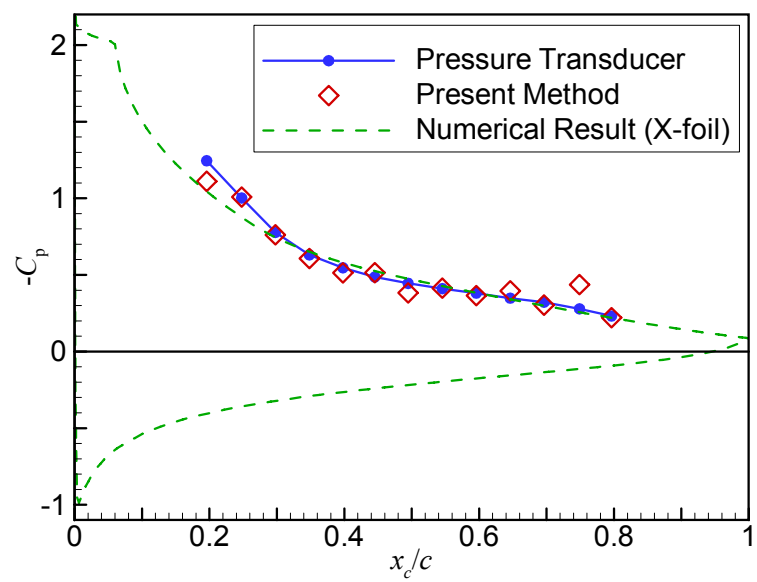

(c) $\alpha=8^{\circ}$

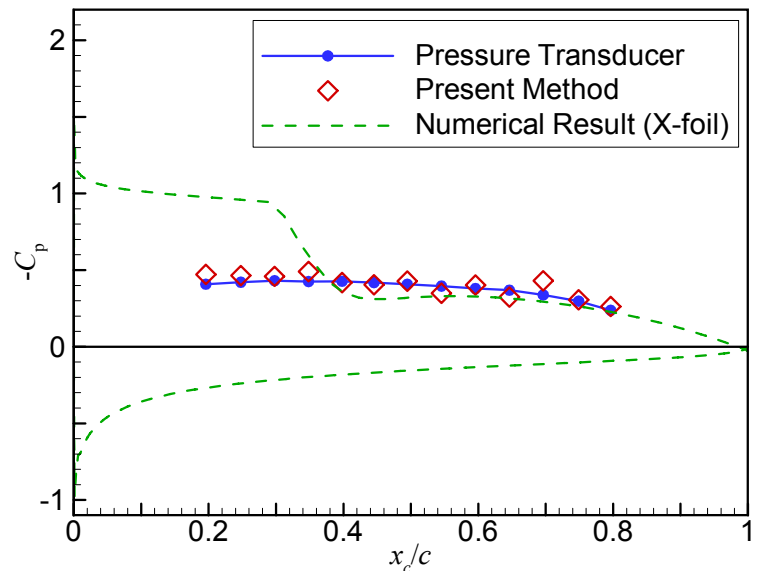

(b) $\alpha=4^{\circ}$

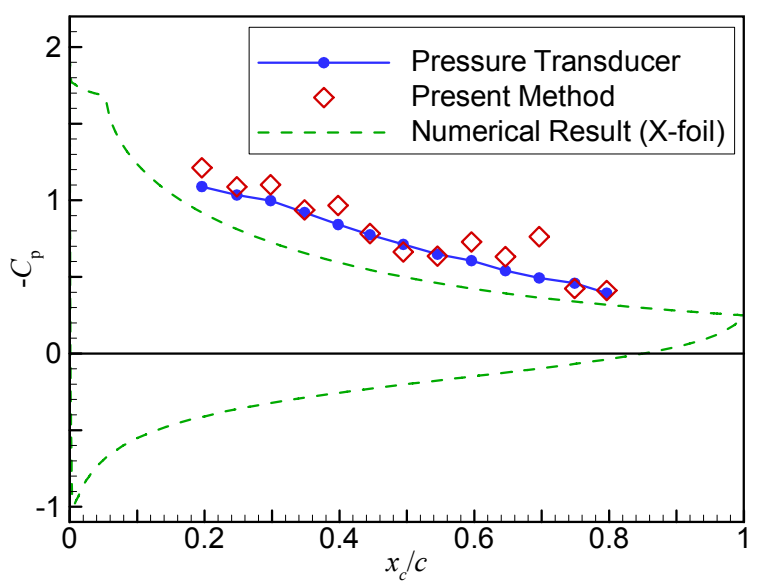

(d) $\alpha=10^{\circ}$

Fig. 12 Pressure coefficient measured by the improved method.

みを計算することで作成された校正曲線をFig. 11 に示す. 校正曲線の傾きは 2 つの校正曲線が平行となる条件で求 めた．全ての穿孔に対しこのような校正曲線が作成され， 2 本の校正曲線の間隔から差圧を求めることが可能であ る.このように校正曲線の間隔から差圧を求める手法で計 算した圧力係数分布と差圧計の結果を比較したものが Fig. 12 である。Fig. 9 の結果に比べ, 測定值のばらつきが小さ くなっている. 通風状態においても, 翼内部の圧力を一定 間隔で加圧して形状測定を行うことで, 測定の不確かさを 小さくすることが可能であるといえる. なお，この手法で も計測值が改善しない測定点も見られる, 今後, 本手法に よる圧力計測の測定を行い, 様々な条件での測定值を比べ ることにより, 何らかの改善方法が見つかることが期待さ れる。

\section{4. まとめ}

レーザ変位計を用いて極薄膜の撓みを測定することに より翼型模型表面の圧力分布を測定する方法を考案し, 風 洞実験を行った. 通風時での測定においても, 模型内部空 間の圧力を変化させた計測を行い微差圧状態にて, 膜の変
形部と平坦部の区別が難しくなることを解決した. 本測定 法で計測した圧力分布は, 翼面上に形成される剥離泡の挙 動を確認する目的を十分満たし, 有益な知見を与えること が明らかとなった。

\section{謝辞}

本研究は, 科学研究費補助金(若手研究 (B) No. 18760606)による支援を受けておこなわれた。また，本風 洞実験を遂行するに当たり，東京大学の砂田保人氏より多 くのご協力をいただいた。ここに感謝の意を表する.

\section{参 考 文 献}

1) McMasters, J.H., and Henderson, M. L. : Low-Speed Single-Element Airfoil Synthesis Technical Soaring, vol.6, No.2 (1980), pp. 1-21.

2) Mueller, T. J. : Aerodynamic Measurements at Low Reynolds Numbers for Fixed Wing Micro-Air Vehicles, RTO AVT/VKI Special Course on Development and Operation of UAVs for Military and Civil Applications, (1999)

3) Mueller, T. J., and DeLurier, J. D. : Aerodynamics of Small Vehicles, Annual Review of Fluid Mechanics, Vol.35 (2003), pp. 89-111. 
4) Tezuka, A., Sunada, Y., and Rinoie, K. : Surface Pressure Distributions on 4\% Circular Arc Airfoil at Low Reynolds Number, Journal of Aircraft, Vol.45, No.6 (2008), pp. 2164-2167.

5) Tashiro, K., Tadokoro, H., and Kobayashi, M. : Structure and piezoelectricity of poly (vinylidene fluoride), Ferroelectrics, Vol. 32, No. 1 (1981), pp. 167-175.

6) Nitsche, W., Mirow, P., and Szodruch, J. : Piezo-Electric Foils as a Means of Sensing Unsteady Surface Forces, Experiments in Fluids, Vol. 7 (1989), pp. 111-118.

7) Daoud, M, and Naguib, A: A Doppler Sensor for High Spatial Resolution Measurements of Unsteady Surface Pressure,
Measurement Science and Technology, Vol.14 (2003), pp. 13-23.

8) Tezuka, A. : Validation Study of Pressure Measurement System with Laser Displacement Sensor and Film, AIAA Paper 2008-0272 (2008).

9）手塚巠聖：レーザ変位計を用いた膜の撓み計測による翼表面圧力分 布測定の検証, 第 40 回流体力学講演会講演集, (2008), pp. 353-356.

10) Drela, M., Giles, M. B. : Viscous-Inviscid Analysis of Transonic and Low Reynolds-Number Airfoils, AIAA Journal, Vol. 25, No. 10 (1987) pp. 1347-1355.

11）手塚亜聖, 砂田保人, 李家賢一：4\%キャンバー翼の低レイノルズ数 空力特性に対する実験的及び数值的研究, 日本航空宇宙学会第 38 期 年会講演会講演集, (2007), pp. 183-186. 